\title{
SYNTHESIS OF LOW-COST MAGNETITE NANO-ARCHITECTURES FROM SRI LANKAN LATERITES
}

\author{
D.M.S.N. DISSANAYAKE ${ }^{1 *}$, M.M.M.G.P.G. MANTILAKA ${ }^{1}$, H.M.T.G.A. PITAWALA ${ }^{1,2}$ \\ ${ }^{1}$ Postgraduate Institute of Science, University of Peradeniya, Peradeniya, Sri Lanka
}

${ }^{2}$ Department of Geology, Faculty of Science, University of Peradeniya, Peradeniya, Sri Lanka

*Corresponding authors: e-mail-dmsndissanayake@ hotmail.com

(Received 15 $5^{\text {th }}$ January 2020; accepted $16^{\text {th }}$ May 2020)

\begin{abstract}
Magnetite nanomaterials are immensely valuable in the biomedical, water science, electronic and bioengineering fields because of their para-magnetic property and biocompatibility. Nevertheless, the cost of these materials is very high although it is regularly used in most applications in modern industries. To address the issue, the present study is focused to synthesize magnetite nano-spheres assembled nanoarchitectures. The low cost and locally available laterite was used as a source of iron. The extracted iron was purified and converted into magnetite by a sol-gel synthesis method. The synthesized iron nanoparticles were characterized using X-ray diffraction (XRD), Scanning Electron Microscopic (SEM) and Thermogravimetric (TG) techniques. The obtained results confirmed that $50 \mathrm{~nm}$ of spherical magnetite particles were formed. Also, the particles showed some picturesque self-assemblies when the $\mathrm{pH}$ of the precursor-solution of the sol-gel process and the rate of annealing are changed. TG analysis reveals that the annealing temperature is $500^{\circ} \mathrm{C}$. X-ray diffraction pattern of the product is comparable with commercially available nano-magnetite as well as the same material produced using chemicals using the same method. These prepared nano-architectures have potential applications in drug delivery, electronic devices and medical imaging.
\end{abstract}

Keywords: Laterite, Magnetite, Nano-architectures, Sol-gel synthesis

\section{INTRODUCTION}

In recent years, an increasing number of applications and products containing or using nanomaterials have become available. Nanotechnologies include the development and production of nano-sized particles, fibers and coatings, as a group referred to as nanomaterials. They are having particles or constituents of nanoscale dimensions (1-100 $\mathrm{nm})$ and are intentionally manufactured materials. When the particles are at the nanoscale, compared to the macro- or microscale particles, the properties of the material change in terms of physically, chemically and mechanically. Nanomaterials are becoming more and more popular in modern industrial fields because the advancements of nanoscience are touching almost every aspect of modern science including biomedical, engineering, electronic, energy, textile, environmental, etc. (Roco et al., 2000; Uskoković, 2007). At present, there is an everincreasing demand for low-cost nanomaterials produced from less expensive raw materials since the conventional production cost of these nanomaterials is immensely high.

Among these nanomaterials, magnetite is relatively expensive. However, it is commonly used nanomaterial since it has para-magnetic properties, besides other properties such as biocompatibility, chemical inertness, thermal stability etc. Therefore, the synthesis of magnetite nanoparticles has been intensively developed for many technological applications such as magnetic resonance imaging (MRI) (Ito et al., 2005; Stephen et al., 2011), nanotagging (Wang et al., 2005), wastewater treatment ( $\mathrm{Su}$ and Puls, 2008; Vergés et al., 2008; Navratil and Akin, 2009; Yang et al., 2010; Carlos et al., 2013), ferrofluids (Orsucci 
and Sala, 2013), drug delivery (Avilés et al., 2008; Kempe and Kempe, 2010; Mangual et al., 2011; Arias et al., 2012), tissue engineering (Shimizu et al., 2006) and so on. However, the production of magnetite nanoparticles (MNP) requires high energyconsuming production processes, expensive precursor materials and time-consuming long processes all of which lead to multiplied cost, energy wastage and environmental impacts. Hence, the production of magnetite nanomaterials by low-cost methods using less expensive raw-materials is a timely needed requirement as the demand for such nanomaterials is ever getting high with the technological advancements and scientific discoveries in biomedical science, engineering and water science (Inshakova and Inshakov, 2017). To fulfil the local and global demand, mineral resources available in Sri Lanka such as marble, mica and graphite have been used to synthesize nanomaterials (Mantilaka et al., 2014a; b; Priyadarshana et al., 2015; Somarathna et al., 2016; Wijesinghe et al., 2017; Senthilnathan et al., 2019).

In the present study, we focused to develop a low-cost, industrially viable method to produce MNPs from commonly available laterite in Sri Lanka. Laterites are composed of primary and secondary mineral formations such as quartz, goethite, hematite, kaolin, and other clay minerals (Sivarajasingham et al., 1962; Dissanayake, 1980; Haldar, 2013). They have been derived from the chemical weathering of the parent rocks with the leaching of mobile elements by infiltrated waterways and groundwater fluctuations (Dahanayake, 1982). According to previous studies on Sri Lankan laterites, they are extensively distributed in the southwestern region of the island as shown in Figure 1 (Dissanayake, 1980; Dahanayake, 1982; Herath and Pathirana, 1983). Also, some other laterite deposits are found in Anuradhapura, Puttalam, Matale and Badulla districts (Dahanayake, 1982).

Nano-architectures are the nanoscale architectures with definite shape and are made up of nanoparticles which serve as building blocks (Grill et al., 2007). These nanoarchitectures are very useful in modern technologies such as energy storage (Summers et al., 2003), catalysis and sensing (Ohmura et al., 2019) drug delivery (Gunkel-Grabole et al., 2015), and nano-electronics (Wang et al., 2006). The initial step of the method of the present study is to extract iron $\left(\mathrm{Fe}^{3+}{ }_{\text {(aq) }}\right)$ from laterite by acid leaching. The extracted iron is converted into MNP by the sol-gel method (Zhu et al., 2012; Brinker and Scherer, 2013).

\section{MATERIALS AND METHODS}

\section{MATERIALS}

Laterite samples were collected from Homagama, Sri Lanka, where longitudes and latitudes of the area were $80.0377^{\circ}$ and $6.8267^{\circ}$, respectively (Figure 1). Hydrochloric acid (38\% assay and 99\% purity), nitric acid (69\% purity), sodium hydroxide (99\% purity), ethylene glycol (pure) were used for the extraction of iron from laterite and for the synthesis of MNPs. All the chemicals were purchased from Sigma-Aldrich. All chemicals were of analytical grade and used without any further purification.

\section{EXTRACTION OF Fe ${ }^{3+}$ FROM LATERITES}

Collected laterite samples were washed with pure water to remove any soil and plant materials retain in the rock and dried for two days at $50^{\circ} \mathrm{C}$ in a drying oven. Then the samples were crushed and powdered using a ball mill and $1 \mathrm{~g}$ of this powder was mixed with $5 \mathrm{~mL}$ of concentrated $\mathrm{HNO}_{3}$ and $5 \mathrm{~mL}$ of distilled water. The mixture was heated at $100^{\circ} \mathrm{C}$ for $2 \mathrm{~h}$ or until changing the colour from reddish-brown to yellowish-brown. Finally, the mixture was kept under the room temperature for cooling and the supernatant was separated by centrifuging and vacuum filtration. The concentrated supernatant was mixed with $10 \% \mathrm{NaOH}$ solution with magnetic stirring until the $\mathrm{pH}$ of the solution was to reach 14. The brownish precipitate was separated and washed with warm distilled water 3 times (Dissanayake et al., 2019a; b; Chandrakumara et al., 2019) The precipitate 
was re-dissolved in $1 \mathrm{ml}$ of $(69 \%) \mathrm{HNO}_{3}$ with $5 \mathrm{~mL}$ of distilled water at $80^{\circ} \mathrm{C}$. Here onwards the solution is referred to as "Fe extract".

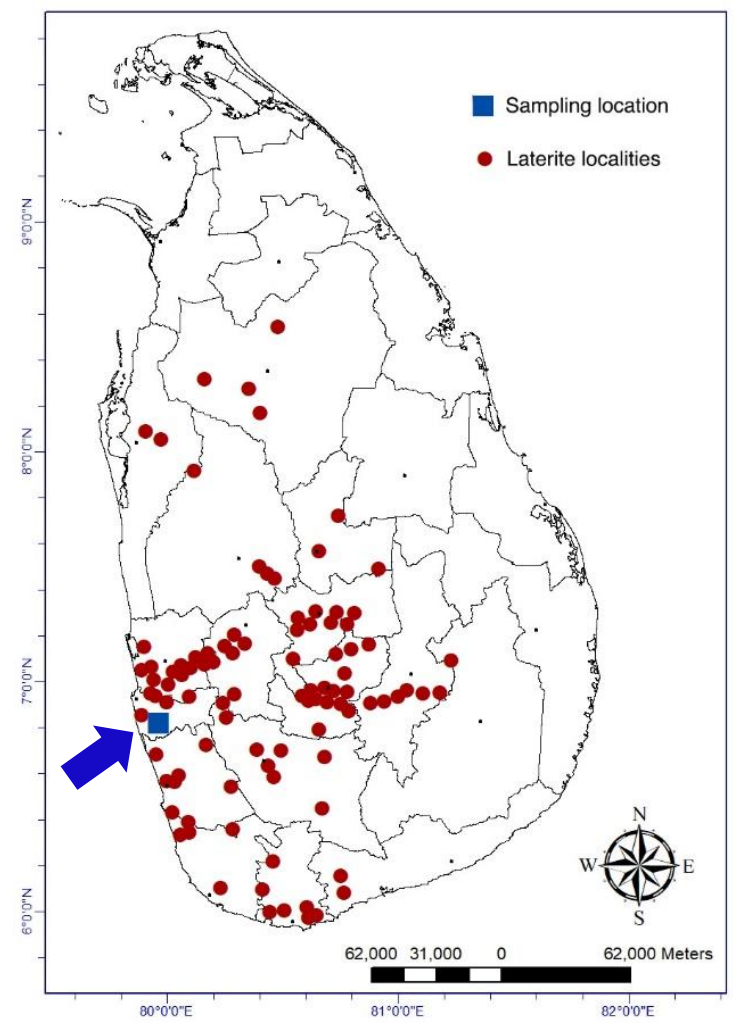

Fig. 1. Map showing laterite occurrences in Sri Lanka (Modified after Dissanayake, 1980, Dahanayake, 1982, Herath and Pathirana, 1983) and the sampling location of current study.

\section{SYNTHESIS OF MNP}

$1 \mathrm{~mL}$ of the Fe extract was then mixed with 1 $\mathrm{mL}$ of ethylene glycol and stirred at $80^{\circ} \mathrm{C}$ until the mixture became viscous. Then the temperature of the mixture was raised to $120^{\circ} \mathrm{C}$ until it forms a very thick gel. The gel is then transferred into a crucible and calcined in a muffle furnace at $500^{\circ} \mathrm{C}$ for one hour. Then the prepared powder was allowed to cool under room temperature. Ten per cent (10\%) $\mathrm{HCl}$ solution heated at $80^{\circ} \mathrm{C}$ was added into the cooled extract and stirred for $15 \mathrm{~min}$. After stirring, the precipitate was separated by centrifugation and washed with warm $\left(50^{\circ} \mathrm{C}\right)$ distilled water for 3 times. Then the powder was dried in an oven at $50^{\circ} \mathrm{C}$ until the product become a fully dry material.

\section{CHARACTERIZATION TECHNIQUES}

Synthesized products and raw-materials were characterized by various analytical techniques. $\mathrm{X}$-ray diffraction (XRD) technique was used to identify the crystalline phases of laterites and synthesized products with the help of Rigaku Ultima IV X-ray Diffractometer operating with a $\mathrm{Cu}-\mathrm{K} \alpha-1$ radiation source filtered with a curved single crystal graphite monochromator $(\lambda=1.54056 \AA)$. XRD patterns were recorded from $2 \theta$ values from $5^{\circ}$ to $80^{\circ}$ with $0.02^{\circ}$ stepwidth and $1 \mathrm{~s}$ counting time for each step. The XRD data were analysed using the DIFFRACPlus EVA program, and the patterns were identified using the ICDD PDF 2 database. Hitachi SU6600 Scanning electron microscope (SEM) was used to observe the morphology and particle size of synthesized iron oxide nanoparticles. Thermal characteristics of the precipitates obtained were studied with thermogravimetric analysis (TGA) which was conducted using a TA SDT Q600 instrument under atmospheric conditions at a heating rate of $20^{\circ} \mathrm{C} \mathrm{min}^{-1}$ from $50^{\circ} \mathrm{C}$ to $500^{\circ} \mathrm{C}$. The converted percentage of the raw laterite powder after acid treatment was determined by measuring the weight of samples before and after the treatment.

\section{RESULTS AND DISCUSSION}

Laterite consists of several oxides and hydroxides of $\mathrm{Fe}$ and $\mathrm{Al}$ as well as silicate minerals as the major constituents (Sivarajasingham et al., 1962)(Aleva, 1994). The iron in laterite should be extracted out leaving compounds of other minor impurities. Before any extraction process of earth material, it is essential to know the relative chemical composition of the raw materials. Then an appropriate extraction process is decided to depend upon the composition. However, in the case of the composition of laterites in Sri Lanka, it does not spatially differ much concerning those ores in other countries (Dahanayake, 1982). Hence, the method is developed that it would be compatible with any laterite sample found within Sri Lanka. 


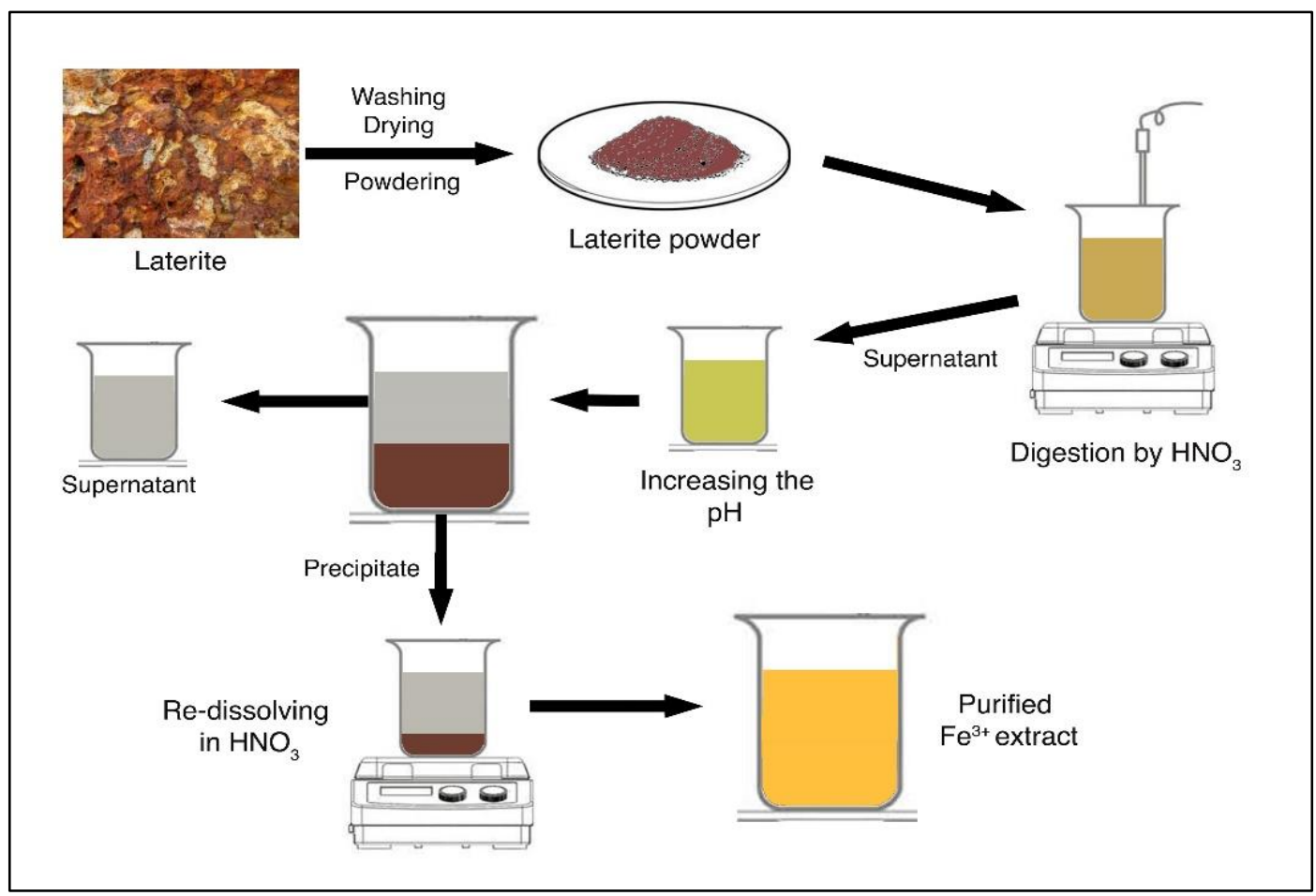

Fig. 2. A summary of the digestion process of laterite from which the purified precursor solution of $\mathrm{Fe}^{3+}$ is synthesized. In this process, the laterite rock is cleaned, powdered, acid leached and the resultant supernatant is purified to get a pure $\mathrm{Fe}^{3+}$ solution.

\section{THE EXTRACTION PROCESS OF Fe $\mathrm{e}^{3+}$}

The laterite sample used for this study was selected from an area in which, the laterites show relatively high $\mathrm{Fe}$ content when compared to the other laterites found in the country (Dissanayake, 1980; Dahanayake, 1982; Herath and Pathirana, 1983). According to the XRD study, the laterites sample is composed of several crystalline mineral phases such as hematite, goethite, dickite, quartz (Dissanayake et al., 2019b).

As shown in Figure 2, the extraction process started with washing and drying the samples to remove any impurities attached to the samples. Then the powdered samples were used for the acid digestion process. $\mathrm{HNO}_{3}$ was used as it is the most suitable acid for dissolving $\mathrm{Fe}^{3+}$. Further, the acid is decomposed into $\mathrm{NO}_{2}$ and $\mathrm{O}_{2}$ during the annealing process as described below (see Equation 1, 2). Compared to $\mathrm{HNO}_{3}$, other common acids such as $\mathrm{H}_{2} \mathrm{SO}_{4}$ and $\mathrm{HCl}$ are not suitable due to the following reasons. $\mathrm{HCl}$ is more reactive but upon annealing, it retains $\mathrm{Cl}^{-}$impurities in the final product and a lot of washing steps should be needed in the process to remove the impurities. In the case of $\mathrm{H}_{2} \mathrm{SO}_{4}$, the solubility of $\mathrm{Fe}^{3+}$ is very low compared to other acids. Therefore, the quantity of the final product is relatively less. Once the powder is digested, the supernatant (SUP-1) is separated by 3 step filtrations (gravity separation, centrifuging and vacuum filtration) because this separation ensures that any undigested matter has not retained in the final solution.

SUP-1 contains $\mathrm{Fe}^{3+}$ as the major ion but minor impurities of $\mathrm{Al}^{3+}$ can be present in the solution (Dissanayake et al., 2019a). The $\mathrm{pH}$ of the solution is brought up to 14 to remove this impurity, where the $\mathrm{Fe}$ precipitates as $\mathrm{Fe}(\mathrm{OH})_{3}$ and $\mathrm{Al}^{3+}$ turns into aqueous $\mathrm{AlO}_{2}^{-}$ ions where the two elements are in two separate phases which can be separated very easily. 


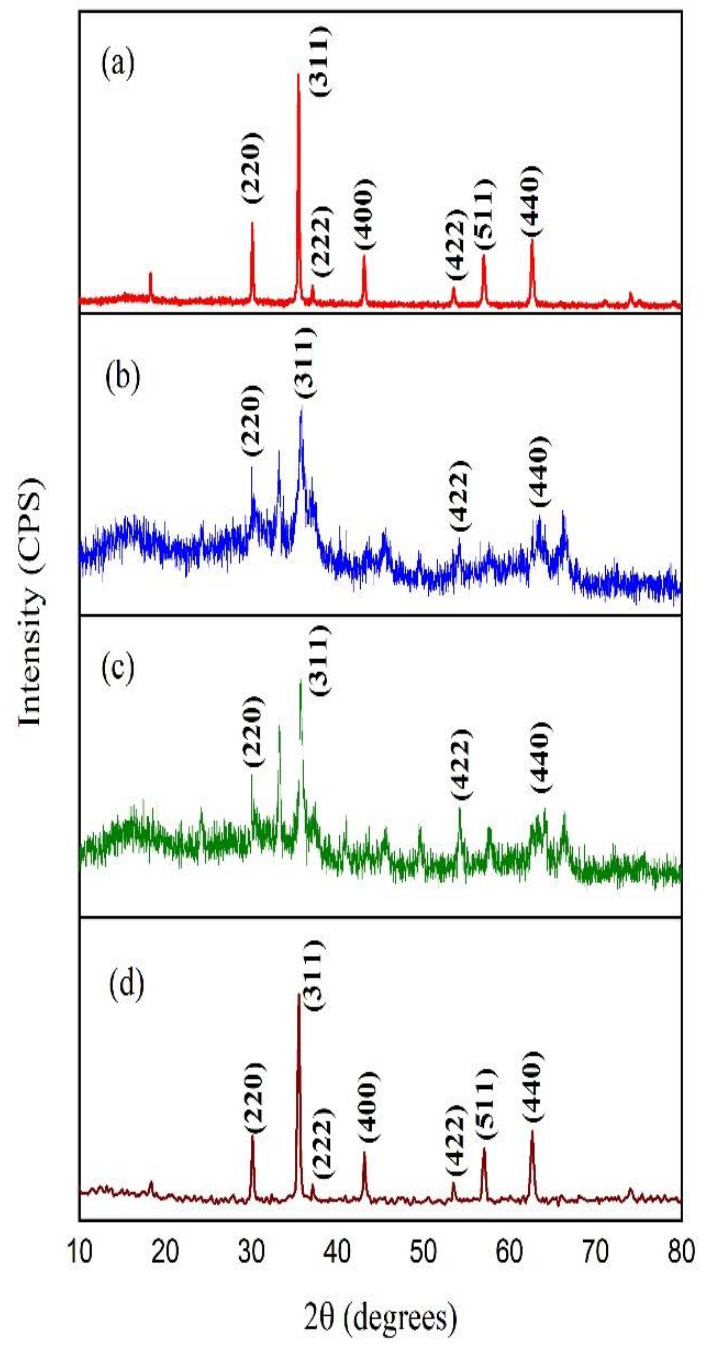

Fig. 3. XRD pattern comparison of the (a) Commercially available magnetite powder; (b) MNP produced using $\mathrm{Fe}\left(\mathrm{NO}_{3}\right)_{3}$ salt; (c) $M N P$ before the $\mathrm{HCl}$ treatment; (d). MNP after the $\mathrm{HCl}$ treatment. Graph (b) and (c) shows the presence of minor amount of maghemite which is also a para magnetic mineral phase (JCPDS card number 040755). Magnetite in all XRD patterns belong to the JCPDS card number 19-0629 and the corresponding hkl values shown belong to the same mineral phase.

\section{SYNTHESIS AND CHARACTERIZATION OF MAGNETITE}

In the current process ethylene glycol (EG) acts as a monomer to produce polyethylene glycol (PEG) upon polymerization in the atmospheric conditions under heat and produce a network of polymeric PEG molecules trapping the precursors, $\mathrm{Fe}^{3+}$ with
$\mathrm{NO}_{3}{ }^{-}$ions. During annealing, the nitrate ions decompose into $\mathrm{NO}_{2}$ and $\mathrm{O}_{2}$ and $\mathrm{O}_{2}{ }^{-}$free radicals (Equation 1) to provide a necessary reducing agent to facilitate the reduction of $\mathrm{Fe}^{3+}$ into $\mathrm{Fe}^{2+}$ which is crucial for the formation of magnetite $\left(\mathrm{Fe}^{2+} \mathrm{O} \cdot \mathrm{Fe}_{2}{ }^{3+} \mathrm{O}_{3}\right.$, Equation 2/3).

$$
\begin{aligned}
& 4 \mathrm{NO}_{3}^{-} \rightarrow \mathrm{O}_{2}^{--}+4 \mathrm{NO}_{2}+\mathrm{O}_{2} \\
& \mathrm{Fe}^{3+}+\mathrm{O}_{2}^{\circ-} \rightarrow \mathrm{Fe}^{2+}+\mathrm{O}_{2} \\
& 2 \mathrm{Fe}^{3+}+\mathrm{Fe}^{2+}+2 \mathrm{O}_{2} \rightarrow \mathrm{FeO} . \mathrm{Fe}_{2} \mathrm{O}_{3}(3)
\end{aligned}
$$

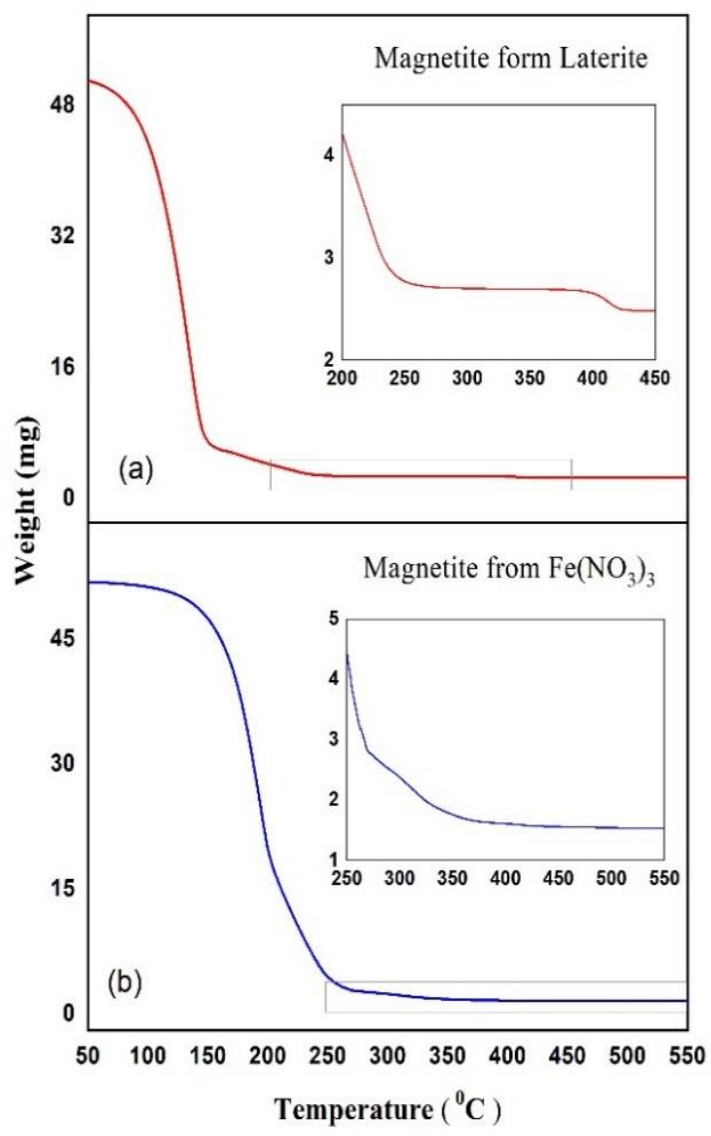

Fig. 4. TGA curves of magnetite produced from (a) Laterites; (b) $\mathrm{Fe}\left(\mathrm{NO}_{3}\right)_{3}$; that shows the thermal behaviour of the gel in the annealing step.

\section{CHARACTERIZATION OF MATERIALS USING XRD}

The XRD pattern of the prepared MNP is shown in Figure $3 \mathrm{~d}$ and the pattern is almost similar to that of commercially available magnetite (Figure 3a) prepared by the same method using $\mathrm{Fe}\left(\mathrm{NO}_{3}\right)_{3}$ as a precursor (Figure $3 \mathrm{~b}$ ), it can be observed that majority of peaks are 

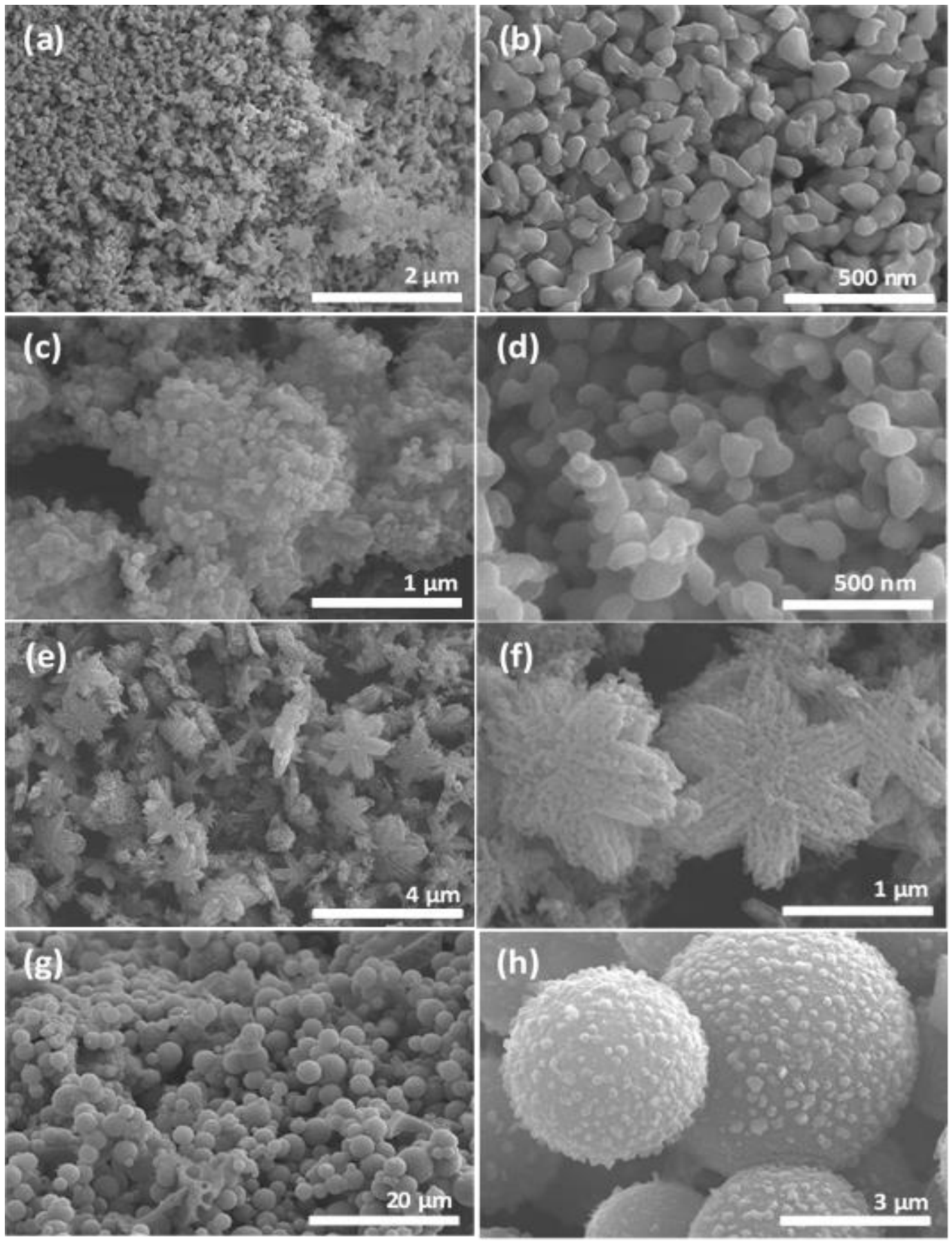

Fig. 5. Scanning electron micrographs of the prepared magnetite particles by; (a), (b) $\mathrm{Fe}\left(\mathrm{NO}_{3}\right)_{3} ;(\mathrm{c})-(\mathrm{h})$ Laterites with different self-assemblages of nanoparticles where $(c)$ and $(d)$ showing the original bare MNP; $(e)$ and $(f)$ showing the star-like architecture; $(g)$ and (h) showing the spherical architecture. 
corresponding to magnetite (JCPDS card number $19-0629)$ peaks the corresponding $2 \theta$ values $\left(30^{\circ}, 36^{\circ}, 37^{\circ}, 43^{\circ}, 53^{\circ}, 57^{\circ}, 62.5^{\circ}\right)$ corresponding lattice parameters [(220), (311), (222), (400), (422), (511), (440)]. However, there are some other peaks which correspond to maghemite (JCPDS card number 04-0755). This mineral phase is identified as a minor impurity phase in the final product and the final acid wash step removes this impurity since maghemite is relatively dissolved in $\mathrm{HCl}$ than magnetite (Figure 3c and 3d).

\section{THERMAL CHARACTERIZATION}

Since all water in the precursor mixture was evaporated out, there is no mass loss around $100^{\circ} \mathrm{C}$ (Figure 4). When comparing the magnetite formed from the $\mathrm{Fe}$ extract and $\mathrm{Fe}\left(\mathrm{NO}_{3}\right)_{3}$, the only difference is that the $\mathrm{Fe}$ extract is more acidic than the latter solution. The main mass drop which represents EG evaporation and nitrate decomposition are not identical in Figure 3. The reason for this is Nitrates decompose around 100-250 ${ }^{\circ} \mathrm{C}$ (Małecka et al., 2015) and EG evaporate at around $150-200{ }^{\circ} \mathrm{C}$. As the final step, the PEG matrix that surrounds the particle reaction sites decompose around $300-450^{\circ} \mathrm{C}$ revealing the required $\mathrm{MNP}$, without any precursors left out in the solid phase.

\section{MORPHOLOGICAL CHARACTERISATION}

Figure 5 summarizes the morphological characteristics of the prepared products. Magnetite produced by $\mathrm{Fe}\left(\mathrm{NO}_{3}\right)_{3}$ shows the particle size in a range of 50-70 nm (Figures $4 \mathrm{a}$ and $4 \mathrm{~b}$ ). However, the diameter of other synthesized magnetite particles has in a range of 30-50 nm. Figure $4 \mathrm{c}$ and $4 \mathrm{~d}$ show the bare nanoparticles which obtained from the synthesis process. It is interesting to observe that a distinguished nano-architectures have been formed at very low $\mathrm{pH}$ (lower than 1) and low rate of heating during the annealing process [see Figure $4(\mathrm{e}, \mathrm{f})$ and $(\mathrm{g}, \mathrm{h})$ ], they appear as micro-scale assemblages of hexagonal-shaped stars and a very distinctive ball-like architecture. To understand the formation mechanism of these architectures, it is important to know that once the nanoparticles are formed in the precursor solution, they tend to reduce their surface energy by reducing the surface area. This is achieved by agglomeration or aggregation of the particles together as clusters. When the precursor solution is extremely acidic $(<1)$; the resultant gel becomes crowded with $\mathrm{H}^{+}, \mathrm{Fe}^{3+}$ and $\mathrm{NO}_{3}^{-}$ions inside the PEG network. When the gel gets annealed, depending on the rate of heating, the prepared particles tend to aggregate in a controlled mechanism. This results in definite shapes of the clusters that are formed to reduce their surface energies.

The percentage of laterite that converted into MNP just after the annealing $44.32 \%$ by weight. After the maghemite, the purified MNP percentage of $40.15 \%$. Among most studies related to value addition to minerals and related materials, synthesizing magnetite from those kinds of resources has captured the attention of scientists. Some of these materials include iron ore tailings and mineral waste (Giri et al., 2011; Wu et al., 2011; Kumar et al., 2015). However, laterite has never been utilized as a raw material for synthesizing any nanomaterial yet. Nevertheless, with the low material cost and the higher price of magnetite, it is profitable to start new industries related to nanotechnology. Because properly optimized magnetite nanoparticles can be used mostly in the biomedical fields and also in other fields including water treatment, sensing and electronics (Majewski and Thierry, 2008).

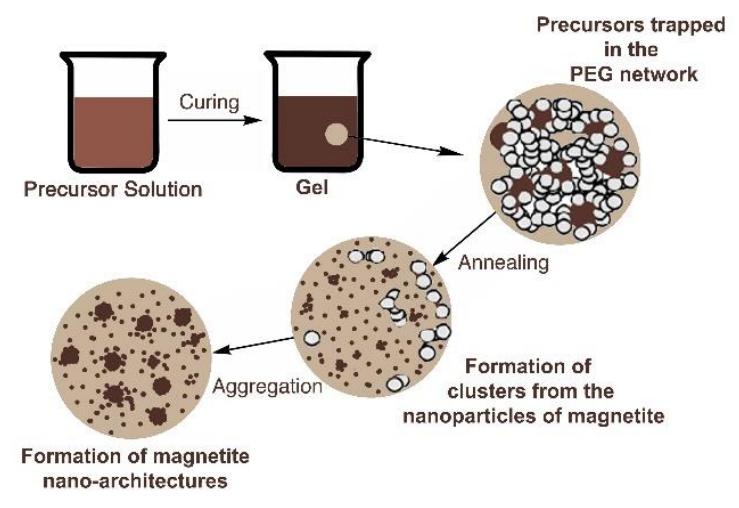

Fig. 6. Schematic illustration showing possible formation mechanism of as synthesized magnetite nano-architectures. 


\section{CONCLUSIONS}

Laterite is an economically useful natural resource for the production of MNP and their nano-architectures. The prepared product proved to be effective because of their nanoscale particle diameter $(50 \mathrm{~nm})$ as revealed from the SEM studies. Further, it is indicated that about $40.15 \%(\mathrm{w} / \mathrm{w})$ of iron has been transformed into the final product. The method is designed as that it can be easily scaled-up to pilot plant level because it uses a very simple method that uses very basic chemical phenomena and uses minimum materials and energy for the production.

\section{ACKNOWLEDGEMENTS}

The authors would like to acknowledge the National research council of Sri Lanka (Grant no-16-123) for the financial support and Sri Lanka Institute of Nanotechnology for the instrumentation facilities.

\section{REFERENCES}

Aleva, G.J.J. (1994) Laterites: Concepts, geology, morphology, and chemistry: Wageningen. Netherlands, International Soil Reference and Information Centre (ISRIC).

Arias, J.L., Reddy, L.H. and Couvreur, P.(2012) $\mathrm{Fe}_{3} \mathrm{O}$ //chitosan nanocomposite for magnetic drug targeting to cancer. Journal of Materials Chemistry, 22, $7622-7632$.

Avilés, M.O., Ebner, A.D. and Ritter, J.A. (2008) In vitro study of magnetic particle seeding for implant assisted-magnetic drug targeting. Journal of Magnetism and Magnetic Materials, 320, 2640-2646.

Carlos, L., Garcia Einschlag, F.S., C., M. and O., D. (2013) Applications of Magnetite Nanoparticles for Heavy Metal Removal from Wastewater. In: Waste Water Treatment Technologies and Recent Analytical Developments. InTech,.

Chandrakumara, G.T.D., Dissanayake, D.M.S.N., Mantilaka, M.M.M.G.P.G., De Silva, R.T., Pitawala, H.M.T.G.A. and de Silva, K.M.N. (2019) EcoFriendly, Green Packaging Materials from Akaganeite and Hematite Nanoparticle-Reinforced Chitosan Nanocomposite Films. Journal of Nanomaterials, 2019, 1-11.

Dahanayake, K. (1982) Laterites of Sri Lanka - A reconnaissance study. Mineralium Deposita, 17, 245-256.

Dissanayake, C.B. (1980) Mineralogy and chemical composition of some laterites of Sri Lanka. Geoderma, 23, 147-155.

Dissanayake, D.M.S.N., Mantilaka, M.M.M.G.P.G., Palihawadana, T.C., Chandrakumara, G.T.D., De Silva, R.T., Pitawala, H.M.T.G.A., Nalin de Silva, K.M. and Amaratunga, G.A.J. (2019a) Facile and low-cost synthesis of pure hematite $\left(\alpha-\mathrm{Fe}_{2} \mathrm{O}_{3}\right)$ nanoparticles from naturally occurring laterites and their superior adsorption capability towards acid-dyes. RSC Advances, 9, 2124921257.

Dissanayake, D.M.S.N., Mantilaka, M.M.M.G.P.G., De Silva, R.T., Pitawala, H.M.T.G.A., Nalin De Silva, K.M. and Amaratunga, G.A.J. (2019b) Cost effective, industrially viable production of $\mathrm{Fe} 2 \mathrm{O} 3$ nanoparticles from laterites and its adsorption capability. Materials Research Express, 6, 105077.

Giri, S.K., Das, N.N. and Pradhan, G.C. (2011) Synthesis and characterization of magnetite nanoparticles using waste iron ore tailings for adsorptive removal of dyes from aqueous solution. Colloids and Surfaces A: Physicochemical and Engineering Aspects.

Grill, L., Dyer, M., Lafferentz, L., Persson, M., Peters, M. V. and Hecht, S. (2007) Nano-architectures by covalent assembly of molecular building blocks. Nature Nanotechnology, 2, 687-691.

Gunkel-Grabole, G., Sigg, S., Lomora, M., Lörcher, S., Palivan, C.G. and Meier, W.P. (2015) Polymeric 3D nanoarchitectures for transport and delivery of therapeutically relevant biomacromolecules. Biomaterials Science, 3, 25-40.

Haldar, S.K. (2013) Exploration Geochemistry. In: Mineral Exploration. Elsevier, 55-71.

Herath, J.W. and Pathirana, H.C.N.C. (1983) Genesis and constitution of Sri Lanka laterites. Journal of the National Science Foundation of Sri Lanka, 11, 277. 
Inshakova, E. and Inshakov, O. (2017) World market for nanomaterials: Structure and trends. MATEC Web of Conferences, 129, 02013.

Ito, A., Shinkai, M., Honda, H. and Kobayashi, T. (2005) Medical application of functionalized magnetic nanoparticles. Journal of Bioscience and Bioengineering, 100, 1-11.

Kempe, H. and Kempe, M. (2010) The use of magnetite nanoparticles for implantassisted magnetic drug targeting in thrombolytic therapy. Biomaterials, 31, 9499-9510.

Kumar, R., Sakthivel, R., Behura, R., Mishra, B.K. and Das, D. (2015) Synthesis of magnetite nanoparticles from mineral waste. Journal of Alloys and Compounds.

Majewski, P. and Thierry, B. (2008) Functionalized Magnetite Nanoparticles - Synthesis, Properties, and Bioapplications. In: Particulate Systems in Nano- and Biotechnologies. CRC Press, 331-352.

Małecka, B., Łącz, A., Drozdz, E. and Małecki, A. (2015) Thermal decomposition of d-metal nitrates supported on alumina. Journal of Thermal Analysis and Calorimetry, 119, 1053-1061.

Mangual, J.O., Avilés, M.O., Ebner, A.D. and Ritter, J.A. (2011) In vitro study of magnetic nanoparticles as the implant for implant assisted magnetic drug targeting. Journal of Magnetism and Magnetic Materials, 323, 1903-1908.

Mantilaka, M.M.M.G.P.G., Pitawala, H.M.T.G.A., Karunaratne, D.G.G.P. and Rajapakse, R.M.G. (2014a) Nanocrystalline magnesium oxide from dolomite via poly(acrylate) stabilized magnesium hydroxide colloids. Colloids and Surfaces A: Physicochemical and Engineering Aspects, 443, 201-208.

Mantilaka, M.M.M.G.P.G., Rajapakse, R.M.G., Karunaratne, D.G.G.P. and Pitawala, H.M.T.G.A. (2014b) Preparation of amorphous calcium carbonate nanoparticles from impure dolomitic marble with the aid of poly(acrylic acid) as a stabilizer. Advanced Powder Technology, 25, 591598.

Navratil, J.D. and Akin, A. (2009) Mine water treatment using magnetite and iron ferrites. International Mine Water Conference, 439-446.

Ohmura, J.F., Burpo, F.J., Lescott, C.J., Ransil, A., Yoon, Y., Records, W.C. and Belcher, A.M. (2019) Highly adjustable 3D nano-architectures and chemistries: Via assembled 1D biological templates. Nanoscale, 11, 1091-1101.

Orsucci, F.F. and Sala, N. (2013) Ferrofluids. In: Ferrofluids. Berlin, Heidelberg, Springer Berlin Heidelberg, 1-157.

Priyadarshana, G., Kottegoda, N., Senaratne, A., De Alwis, A. and Karunaratne, V. (2015) Synthesis of magnetite nanoparticles by top-down approach from a high purity ore. Journal of Nanomaterials, 2015, 1-8.

Roco, M.C., Williams, R.S. and Alivisatos, P. (2000) Nanotechnology research directions: IWGN workshop report: vision for nanotechnology in the next decade. Springer Science \& Business Media

Senthilnathan, A., Dissanayake, D.M.S.N., Chandrakumara, G.T.D., Mantilaka, M.M.M.G.P.G., Rajapakse, R.M.G., Pitawala, H.M.T.G.A. and Nalin de Silva, K.M. (2019) Akaganeite nanorices deposited muscovite mica surfaces as sunlight active green photocatalyst. Royal Society Open Science, 6, 182212.

Shimizu, K., Ito, A. and Honda, H. (2006) Enhanced cell-seeding into 3D porous scaffolds by use of magnetite nanoparticles. Journal of Biomedical Materials Research - Part B Applied Biomaterials, 77, 265-272.

Sivarajasingham, S., Alexander, L.T., Cady, J.G. and Cline, M.G. (1962) Laterite. In: Advances in Agronomy. 1-60.

Somarathna, Y.R., Mantilaka, M.M.M.G.P.G., Karunaratne, D.G.G.P., Rajapakse, R.M.G., Pitawala, H.M.T.G.A. and Wijayantha, K.G.U. (2016) Synthesis of high purity calcium carbonate micro- and nano-structures on polyethylene glycol templates using dolomite. Crystal Research and Technology, 51, 207-214.

Stephen, Z.R., Kievit, F.M. and Zhang, M. (2011) Magnetite nanoparticles for medical MR imaging. Materials Today, 14, 330-338.

Su, C. and Puls, R.W. (2008) Arsenate and arsenite sorption on magnetite: Relations 
to groundwater arsenic treatment using zerovalent iron and natural attenuation. Water, Air, and Soil Pollution, 193, 6578.

Summers, C.J., Neff, C.W. and Park, W. (2003) Active photonic crystal nanoarchitectures. Journal of Nonlinear Optical Physics and Materials, 12, 587597.

Uskoković, V. (2007) Nanotechnologies: What we do not know. Technology in Society, 29, 43-61.

Vergés, M.A., Costo, R., Roca, A.G., Marco, J.F., Goya, G.F., Serna, C.J. and Morales, M.P. (2008) Uniform and water stable magnetite nanoparticles with diameters around the monodomain-multidomain limit. Journal of Physics D: Applied Physics, 41, 134003.

Wang, S.X., Bae, S.Y., Li, G., Sun, S., White, R.L., Kemp, J.T. and Webb, C.D. (2005) Towards a magnetic microarray for sensitive diagnostics. Journal of Magnetism and Magnetic Materials, 293, 731-736.

Wang, X., Liu, F., Andavan, G.T.S., Jing, X., Singh, K., Yazdanpanah, V.R., Bruque, N., Pandey, R.R., Lake, R., Ozkan, M., Wang, K.L. and Ozkan, C.S. (2006) Carbon nanotube-DNA nanoarchitectures and electronic functionality. Small, 2, 1356-1365.

Wijesinghe, W.P.S.L., Mantilaka, M.M.M.G.P.G., Rajapakse, R.M.G., Pitawala, H.M.T.G.A., Premachandra, T.N., Herath, H.M.T.U., Rajapakse, R.P.V.J. and Wijayantha, K.G.U. (2017) Urea-assisted synthesis of hydroxyapatite nanorods from naturally occurring impure apatite rocks for biomedical applications. RSC Advances, 7, 2480624812.

Wu, S., Sun, A., Zhai, F., Wang, J., Xu, W., Zhang, Q. and Volinsky, A.A. (2011) Fe3O4 magnetic nanoparticles synthesis from tailings by ultrasonic chemical coprecipitation. Materials Letters.

Yang, W., Kan, A.T., Chen, W. and Tomson, M.B. (2010) PH-dependent effect of zinc on arsenic adsorption to magnetite nanoparticles. Water Research, 44, 56935701.

Zhu, Y., Inada, H., Hartschuh, A., Shi, L., Della Pia, A., Costantini, G., Vázquez de Parga, A.L., Miranda, R.,
Barbier, A., Mocuta, C., Belkhou, R., Bhushan, B., Hoo, J.H., Park, K.S., Baskaran, R., Böhringer, K.F., Lu, W., Nosonovsky, M., Ham, M.-H., Boghossian, A.A., Choi, J.H., Strano, M.S., Lang, A., Habegger, M.L., Motta, P., Bhushan, B., Bachmann, T., Wagner, H., Brenner, D.W., Chen, J., Shakiba, N., Tan, Q., Sun, Y., Greer, J.R., Laver, M., Khaled, S.M., Parodi, A., Tasciotti, E., Dave, B.C., Lockwood, S.B., Musicanti, C., Gasco, P., Vollrath, F., Booth, A., McIntosh, A.C., Beheshti, N., Walker, R., Larsson, L.U., Copestake, A., Hwang, H., Cho, Y.-K., Chen, J., Chu, M., Gordijo, C.R., Wu, X.Y., Sun, Y., Kolle, M., Steiner, U., Wang, S.-W., Ceyssens, F., Puers, R., Han, X., Mao, S., Zhang, Z., Jiang, L., Lin, L., Ragan, R., Lughi, V., Drummond, C., Ruths, M., Mu, W., Ketterson, J.B., Berini, P., Zhao, Y.-P., Wang, F.-C., Prakash, S., Henley, S.J., Anguita, J. V., Silva, S.R.P., Chanana, M., Mateo, C., Salgueirino, V., CorreaDuarte, M.A., Kar, S., Talapatra, S., Calvo Fuentes, J., Rivas, J., LópezQuintela, M.A. and Tsuda, S. (2012) SolGel Method. In: Encyclopedia of Nanotechnology. Dordrecht, Springer Netherlands, 2459-2470. 